\title{
Cooperation and Development between China and East Africa
}

\author{
Abdilahi Ismail Abdilahi \\ School of Marxism, Wuhan University of Technology, Wuhan, China \\ Email: ibnutiger12@hotmail.com
}

How to cite this paper: Abdilahi, A. I. (2020). Cooperation and Development between China and East Africa. Open Journal of Social Sciences, 8, 153-166.

https://doi.org/10.4236/jss.2020.84011

Received: March 11, 2020

Accepted: April 11, 2020

Published: April 14, 2020

Copyright $\odot 2020$ by author(s) and Scientific Research Publishing Inc. This work is licensed under the Creative Commons Attribution International License (CC BY 4.0).

http://creativecommons.org/licenses/by/4.0/

\begin{abstract}
Under the influence of globalization, the friendly and cooperative relations between China and East African countries have developed rapidly and comprehensively, from the political exchanges of high-level leaders to the all-round close exchanges of the party, government, military, culture, and business, as well as the close cooperation between the two sides in economic and trade. Both indicate that China and East Africa have very close cooperative and development relations; the main reasons for the development of the cooperative relations between the two sides are due to the mutual needs of the two sides, the political situation of these African countries is basically stable, and the Chinese government has strengthened its African policy. Among them, the development of cooperation between China and Somalia can fully illustrate the tremendous efforts made by China and East African countries in bilateral cooperation. As the least developed region in East Africa and the continuous war, China and Somalia have overcome difficulties together. With the efforts of both sides, the continuous development of cooperative relations is promoted. At present, the development of bilateral relations between China and East Africa is satisfactory. There are still some problems in economic and trade cooperation. This article explains and proposes corresponding countermeasures.
\end{abstract}

\section{Keywords}

China, East Africa, Cooperation, Somalia, Problem, Countermeasure

\section{Introduction}

China values its relations with Africa as a whole. East Africa has attracted special attention because of two historical factors: First, as early as the early 15th century, the famous Chinese navigator Zheng He of the Ming Dynasty led a large fleet of ships to "go to the west" and visited East Africa many times (including 
present Somalia and the coast of Kenya). In this area, the Malindi countries of East Africa (now Kenya) also sent to the Ming court; the second is the start and end of the famous and contemporary China-Africa largest project Tanzania-Zambia Railway and most sections in Tanzania in East Africa ( $\mathrm{He} \& \mathrm{Li}$, 2014). It is an important method for China to assist the African people to realize their liberation. Since the 1990s, China's friendly and cooperative relations with East African countries have continued to develop steadily and rapidly, and entered a period of comprehensive friendly cooperation with some countries. The two sides have carried out all-round close exchanges from the political exchanges of high-level leaders to the party, government, military, culture and business circles, and also have close cooperation in economic and trade matters.

\section{Friendly Cooperation and Exchanges between China and East African Countries in Economic and Cultural Aspects}

China has long established diplomatic relations with East African countries and has signed economic, technological and cultural cooperation agreements with almost all East African countries. Since the 1960s, friendly cooperation has continued to develop, and in the 1990s, especially in the later period, it has developed more rapidly.

\subsection{Increased Exchanges of High-Level Leaders}

Most of the leaders of East African governments, including the president and the prime minister, have visited China, and some have visited many times. For example, former Tanzanian President Nirel and Kenyan President Moi have visited China five and three times. Chinese leaders, including the Chairmen and Vice-Chairmen, the Prime Minister and Deputy Prime Minister, the Chairman of the Standing Committee of the National People's Congress, and the Chairman of the National Committee of the Chinese People's Political Consultative Conference, have also visited East African countries; visits have been frequent since the 1990s. Premier Li Peng of the State Council visited Tanzania. Li Peng, chairman of the Standing Committee of the National People's Congress, visited Kenya in 1999. In 2002, Premier Zhu Ji of the State Council visited Kenya. In 2006, President Hu Jintao visited Kenya. Xi Jinping visited Africa in 2018 and met with leaders of the East African Community.

\subsection{All-Round Exchanges between the Party, Government, Military, Culture, and Business}

Since the 1990s, exchanges between the ministries of the two governments have increased. The Chinese Ministry of Foreign Affairs has also established regular consultation systems with some countries, such as the Ministry of Foreign Affairs of Kenya. More significant is that China has developed relations between the ruling party and the military with many East African countries. The relationship between the ruling parties was established after 1979. At that time, a 
delegation of Chinese Communist Party workers led by Wu Xueqian, deputy head of the International Department of the CPC, visited Somalia, Tanzania and other countries. By the beginning of 2002, the Chinese Communist Party had established ties with most of the ruling parties in East Africa, including Tanzania, Kenya, Ethiopia, Madagascar, Mauritius, and Djibouti, and visits each other.

Interactions between the military are also noticeable. China's military cooperation and exchanges with Tanzania and Madagascar started earlier, and military leaders of the two countries have exchanged visits long ago. Since 1998, Tanzania's military leaders visiting China include General Mbo, commander of the National Defense Forces, Minister Majogo of the Ministry of National Defense and National Services, and Admiral Vaitala, commander of the National Defense Forces. Eritrea and Ethiopia's defense ministers visited China in 2002. In the same year, China also sent a group of experts to guide mine clearance in Eritrea14 people. Li Da, deputy chief of the General Staff of the Chinese People's Liberation Army, visited Tanzania as early as the 1970s; in 1996, the Chinese People's Liberation Army Lanzhou Military District military friendly delegation visited Uganda, Kenya, Ethiopia, and Eritrea. In recent years, senior generals of the Chinese People's Liberation Army, including Chief of General Staff Fu Quanyou, Deputy Chief of General Staff Qian Shugen, General Li Jinai, political commissar of the General Equipment Department, visited Kenya and Tanzania in 2017. Chinese naval fleet visits Dar es Salaam port in Tanzania.

The cultural and educational cooperation between the two sides has also been continuously expanded. China has signed cultural and educational cooperation agreements with many East African countries. In 2000, the governments of China and Tanzania signed a higher education development cooperation project agreement. The Chinese government provides countries in East Africa with a total of about tens of international student places each year to study in Chinese universities. According to the cooperation agreement between China and the Ministry of Agriculture and Education of Ethiopia, since June 2001, China has sent 72 agricultural and urban vocational teachers to Ethiopia to apply to teach in Ethiopia, training local professional teachers and students. In recent years, the Chinese Ministry of Foreign Affairs has also organized training courses for administrative and technical cadres to provide training services for African countries, and some East African countries have sent representatives to participate. In addition, cultural groups such as the Tianjin Acrobatic Troupe of China and the Kenya Dance Troupe exchanged visits. China has also sent song and dance troupes, acrobatics and folk ensembles to Seychelles and the Comoros and hosted a film week. China continues to send medical teams to Eritrea, Comoros, Seychelles, Djibouti and other countries.

The media of both sides continue to develop cooperative relations. The news from Xinhua News Agency has been widely adopted by newspapers from various countries in East Africa. In May 2001, the governments of China and Kenya signed a cooperation agreement on radio and television. China Central Television sent reporters to Africa (including East Africa) for interviews. In October 
2003, the station continuously broadcast documentaries about Kenya.

\subsection{Rapid Development of Economic and Trade Relations}

Since the late 1990s, economic and trade relations between China and East Africa have developed rapidly. It is mainly reflected in the following aspects:

1) Financial assistance. China continues to provide assistance to countries in East Africa, including interest-free loans, concessional loans, unpaid assistance, personnel training, gifts in kind and debt relief. According to statistics from foreign agencies of the Ministry of Commerce, from 2008 to 2018, China's economic aid to East Africa (excluding Eritrea and Comoros) was about 28 billion yuan. The amount of aid received by various countries ranges from tens of millions to several hundred million yuan. Although China's projects in East Africa no longer have oversized projects like the Tanzania-Zambia Railway, there are more small and medium-sized projects, (Skjerdal, 2009) such as highway construction, well drilling, water supply projects, office and housing construction, and technical reconstruction of formerly aided factories or farms and gifts.

2) Trade. China's trade with East Africa developed rapidly in the late 1990s. According to statistics from China's Customs and Ministry of Commerce in Africa, China's trade with seven East African countries in Kenya, Tanzania, Ethiopia, Mauritius, Madagascar, Djibouti, and Uganda exceeded US\$10 billion in 2018 (Fredrik, 2008). The 7 East African countries account for a small proportion of China's total foreign trade, but they have increased every year, and the growth rate has reached double digits. The specific trade volume and growth trend from 2014 to 2018 are shown in Figure 1.

3) Investment. Chinese investment in East Africa can be said to be from scratch. In the 1990s, under the encouragement of the government, a number of state-owned companies and private enterprises have invested in establishing factories or doing business in East African countries. China has signed bilateral

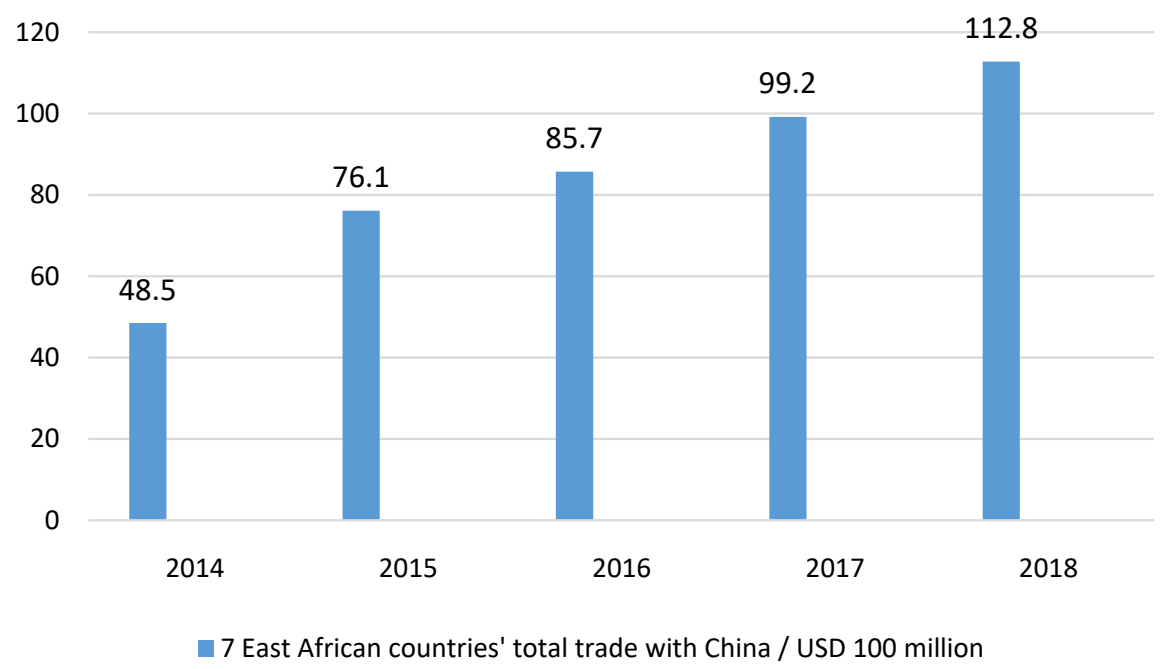

Figure 1. 7 East African countries' total trade with China. 
investment protection agreements with Mauritius, Seychelles, Kenya, and Ethiopia, and has also established investment development and trade promotion centers in Kenya and Tanzania. So far, China's investment has been steadily increasing, and not all companies have succeeded, but some companies have achieved development and benefited themselves and their countries. It is reported that there are nearly 200 Chinese companies of various types in Kenya, most of which have been developed in the past 10 years. In October 2003, the Ministry of Commerce of China issued a document recommending Kenya, Ethiopia, Madagascar and other six countries as key countries for developing textile and apparel processing trade investment in Southeast Africa. Subsequently, Chinese enterprises continued to increase investment in East Africa. A large number of Chinese entrepreneurs chose to open factories in Africa, which not only saved raw material and labor costs, but also improved the local economic level (Stahl, 2012). As an example, China's investment in the seven East African countries has shown a steady and steady growth. The specific data is shown in Figure 2.

4) Engineering contracting. This business has developed rapidly. According to official statistics, China's contracting value and turnover in East Africa have continued to grow. However, the situation is different in different countries. Ethiopia, Tanzania, Kenya, Seychelles and other countries have developed rapidly and a large amount. In addition, the contracting business of Chinese companies with Madagascar and Eritrea is also developing steadily.

5) Labor cooperation. Labor cooperation between China and East African countries is also increasing, although it is still unstable in some countries. According to statistics from the Ministry of Commerce, the contract value and turnover of labor service cooperation have increased from nearly $\$ 1.7$ billion and $\$ 400$ million in 2000-2005 to $\$ 3.48$ billion and \$1.236 billion in 2006-2010. The largest labor service is Mauritius, whose contract value and turnover accounted

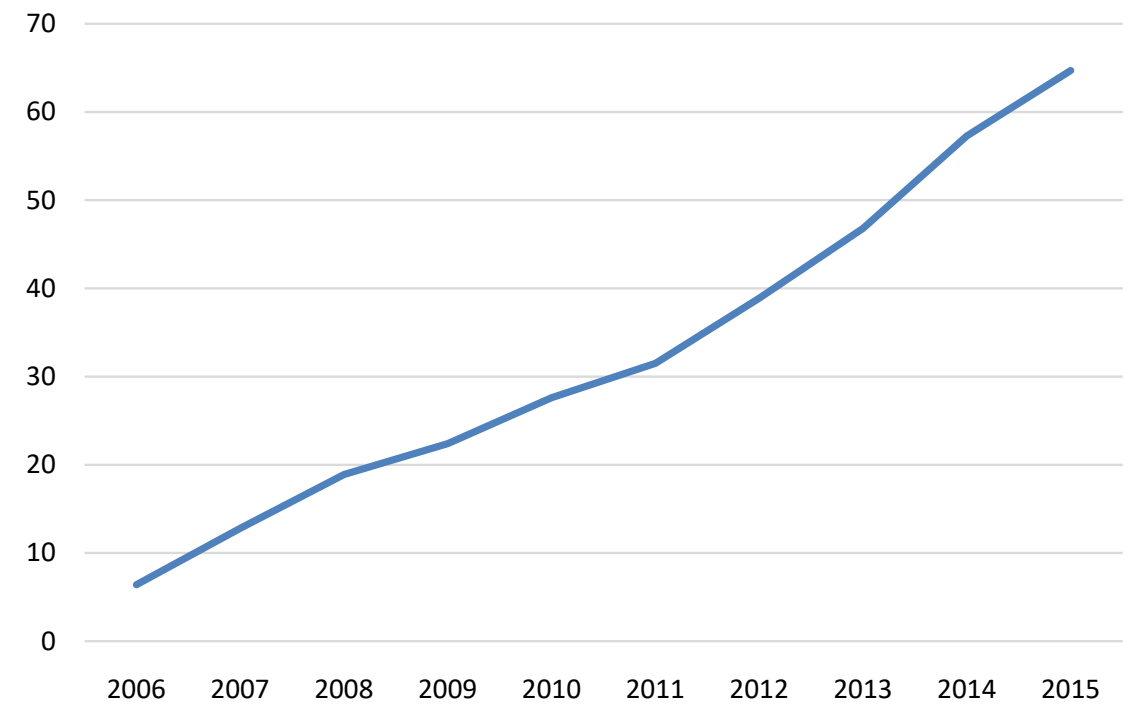

Figure 2. Chinese investment in 7 East African countries. 
for $58.4 \%$ and $67.7 \%$ of the entire East Africa from 2006 to 2010, respectively (Jianxin, 2016). Kenya, Madagascar, and Ethiopia have developed particularly fast, and their labor service contracts have increased by more than 10 times during the same period.

\section{Reasons for the Rapid and Comprehensive Development of Friendly and Cooperative Relations}

China-East Africa friendly and cooperative relations have been developing, especially since the late 1990s, and have developed rapidly and comprehensively. The main reasons are as follows:

\subsection{China's Political Situation Is Stable and Its Economy Continues to Grow at a High Speed}

The political situation of countries in East Africa (except Somalia) is generally relatively stable. Governments of all countries (including governments newly elected through elections) are seeking economic development and are willing to develop friendly and cooperative relations with China. When the foreign minister of Kenya's new government, Musioka, visited China in September 2013, the Chinese and Kenyan governments signed a technical and economic cooperation agreement. Both sides hope to strengthen cooperation in investment and trade. Political stability and desire for friendly cooperation are prerequisites for the development of economic and trade cooperation and friendly relations, and China's economic strength is an important prerequisite.

\subsection{Both Parties Need Each Other}

East African countries need China's support and assistance in international struggles and national development. China is a permanent member of the UN Security Council, and African countries hope that China, on their behalf, will oppose the wanton interference in the internal affairs of African countries in the name of democracy and human rights in the West. Promote the establishment of a new international economic and political order, and safeguard the rights and status of African countries. China can give them more aid with increasing national strength. China needs continued political and diplomatic support from Africa, including East Africa. With the active support of African countries and other countries, China has long resumed its legal seat in the United Nations, but today it still faces several challenges internationally. Very few people in the West continue to cause troubles at home and abroad, so the support of Africa (including East African countries) seems to be Very important. In terms of economic development, although East Africa has so far lacked oil, it has other rich resources. For example, Tanzania has rich water, soil, mineral, aquatic and tropical fruit resources; Uganda has abundant land and water resources; Kenya has a good industrial base and finance. Facilities with rich tourism resources and certain mineral resources; Madagascar has rich mineral, forestry and tropical fruit 
resources; Ethiopia also has rich mineral deposits in addition to agriculture and animal husbandry; Mauritius has rich tourism and fishery resources; Eritrea It is rich in fisheries and certain mineral resources; although Djibouti has fewer resources, it has a better geographical location and financial and trading environment. Its ports and other seaports in East Africa (Mombasa, Dar es Salaam) are all accessible. It is the gateway between East and Central Africa. If China can use and develop these resources reasonably, it will benefit both sides. There are still a large number of Chinese and overseas Chinese in East Africa. For example, there are 30,000 people in Mauritius, about 12,000 in Madagascar, and 2000 in Seychelles. There are also many overseas Chinese in Tanzania and Kenya. Many people have joined the local nationality, but the vast majority of people love the motherland, and the Chinese government has a responsibility to care for them and also needs them to contribute to the cause of the motherland's reunification and development.

\subsection{The Chinese Government Constantly Adjusts Its Policies and Measures in Accordance with Changes in the Situation}

China's Africa policy can be roughly divided into three periods. From the 1950s to the 1970s, he focused on internationalist assistance, made friends, and mentioned "mutual benefit," but as far as China is concerned, it mainly refers to diplomatic and political interests. From the 1980s to the early 1990s, the principles of equality and mutual benefit, diverse forms, and common development were put forward, and cooperation forms such as joint ventures, cooperative management, engineering contracting, and technical training were started. But this is only a trial period. Since the late 1990s, the changes have been greatest. On the basis of the original, Chinese leaders have proposed an economic "going global" strategy, encouraging Chinese public and private enterprises to invest and set up factories abroad, including in East Africa, increase commodity exports, and expand project contracting, technology and technology. It can also help promote the cooperation in labor service and other fields. At the beginning of 1999, when Vice President Hu Jintao visited Uganda and other four African countries, he said, "The Chinese government will continue to provide African countries with government assistance to the best of their ability, without any political conditions. Various forms of economic and trade cooperation, expanding bilateral trade, and seeking common development, make China-Africa cooperation a model of South-South cooperation." This passage focuses on China's current and future policies towards Africa, including East Africa.

In September 2000, China hosted the first Ministerial Conference of the Forum on China-Africa Cooperation. At the meeting, Minister of Foreign Trade and Economic Cooperation Shi Guangsheng made 4 promises on behalf of the Chinese government, namely to gradually expand assistance to Africa as China's national strength grows; within the next two years Relief and relief of RMB 10 billion in debt of the heavily indebted poor and least developed countries in 
Africa; provide special funds to support and encourage strong and credible Chinese companies to invest in Africa and promote African economic development; set up an "African Human Resources Development Fund" to help Africa National training professionals. As mentioned earlier, China honored its commitments and established the Africa Aid Fund, and announced in 2001 that it had reduced or cancelled debts of about 1 billion yuan from East African countries; the convening of a ministerial meeting of the Forum on China-Africa Cooperation and follow-up actions taken by the Chinese government It has promoted the comprehensive and rapid development of China-Africa friendly cooperation. In 2013, General Secretary Xi Jinping proposed the "Belt and Road" initiative, which added new historical significance to China-Africa cooperation, and used this as an opportunity to increase investment and construction in countries along the Belt and Road, and inject into the development of the world economy.

\section{Cooperation between China and Somalia}

The cooperation between China and East Africa was achieved through the unremitting efforts of both sides. The development of cooperation between China and Somalia can fully illustrate the tremendous efforts made by China and East African countries in bilateral cooperation. As the least developed region in East Africa, the war Continuously, China and Somalia have overcome difficulties together, and promoted the continuous development of cooperative relations with the efforts of both sides. The following details the situation in Somalia and the development of cooperation with China.

\subsection{Basic Situation of Somalia}

The Somalia Peninsula, the easternmost part of the African continent, is the junction of Africa and Asia. It faces the Gulf of Aden in the north, faces the Arabian Peninsula across the sea, borders the Indian Ocean in the east, borders Kenya and Ethiopia in the west, crosses the border with Djibouti in the northwest, and crosses the southern end of the equator. The country covers an area of 637,660 square kilometers, including 627,340 square kilometers of land area and 10,320 square kilometers of water area. With a land border of 2340 kilometers and a coastline of 3200 kilometers, it is the country with the longest coastline in Africa. Most regions have a tropical desert climate, and the southwest has a savanna climate, with high temperatures all year round, dry and little rain.

Somalia is one of the least developed countries in the world. The economy is dominated by animal husbandry and the industrial base is weak. In the early 1970s, due to excessive nationalization policies and factors such as natural disasters, the economy was severely difficult. In the 1980s, with the support of the World Bank and the International Monetary Fund, economic policies were adjusted and the economy improved for a time. After 1991, due to internal disturbances, industrial and agricultural production and infrastructure were severely 
damaged, and the economy collapsed. In recent years, the situation in some jurisdictions has been stable and the economy has improved.

The main anti-government force in Somalia is the Al-Shabaab, a youth jihadist organization in Somalia: formerly a youth armed organization under the Somali Anti-Government Alliance of Islamic Courts (ICU), which is mainly responsible for protecting the leader of the alliance and implementing targeting against foreigners Assassination. After the ICU was defeated at the end of 2006, "Sabab" inherited its mantle, and took advantage of the weakness of the Transitional Federal Government and the withdrawal of Ethiopia (Zhang \& Hu, 2016). It became the most powerful anti-government armed group and once controlled most of south-central Somalia. And part of the capital Mogadishu. The organization aims to establish an ultra-Islamic regime in Somalia, and advocates the implementation of strict Islamic law in Somalia to wage jihad against pagans and foreign "aggressors". It was identified as a terrorist organization by the US State Department in 2008. In February 2012, the organization announced that it had formally merged with $\mathrm{Al}$ Qaeda and swore allegiance to Al Qaeda leader Zawahiri. In addition to armed confrontation with the Transitional Government of Somalia and the AU Mission in Somalia, "Sabah" has also frequently carried out terrorist attacks in Somalia and in Uganda, Kenya and other countries. Since the second half of 2011, the organization has been hit hard by the combined efforts of the Somali Security Forces, the AU Mission in Somalia, and the Kenyan and Ethiopian armed forces, and its scope of activities has been significantly reduced. In September 2014, the organization's former top leader, Godani, was killed by US warplanes in southeastern Somalia. This terrorist organization has had a devastating effect on Somalia's politics, economy, and society in the past few years, which has seriously hindered the development of Somalia. At present, the strength of the organization is not as good as before, but it is still an important factor affecting Somalia's economic and social development.

\subsection{Relations between China and Somalia}

China and Somalia established diplomatic relations on December 14, 1960. At the end of 1990, the civil war in Somalia broke out, and the Chinese embassy, medical team and engineering and technical personnel in Somalia were forced to evacuate in January 1991. Since then, the Chinese Embassy in Kenya has taken charge of Somalia-related affairs.

China has always supported and actively promoted the peace process in Somalia, and served as the UN Security Council coordinator in Somalia from 2003 to 2007. After the establishment of the Transitional Federal Government, the Chinese government recognized it and accepted the Ambassador to China appointed by the Transitional Federal Government on December 28, 2005. Since 1992, the Chinese government and the Red Cross have donated a certain amount

of medicines and general supplies to the victims of the disaster each year. In August 2011, to help Somalia respond to drought, the Chinese government pro- 
vided Somalia with 16 million US dollars in food aid cash. President of the Transitional Federal Government Yusuf (presented at the Beijing Summit of the Forum on China-Africa Cooperation in November 2006), Foreign Minister Jama (presented at the Fourth Ministerial Conference of the "China-Arab Cooperation Forum" in May 2010), Fosia (August 2013) successively visited China. In August 2007, Zhang Ming, Chinese ambassador to Kenya, went to Mogadishu, the capital of Somalia, to attend the Somali National Reconciliation Conference and visit Somalia. In November 2012, Chinese Ambassador to Kenya Liu Guangyuan visited Somalia and met with President Mahmoud and other Somalia leaders. Both Somalia's two transitional governments and the formal government established in 2012 attached great importance to relations with China, and reiterated the one-China stance many times, and are willing to further strengthen ties with the Chinese government and develop cooperation with China.

On June 30, 2014, in order to further promote the development of friendly and cooperative relations between China and Somalia, the Chinese government decided to resume the embassy in Somalia and will send a re-embassy team to Somalia on July 1 . The restoration team arrived in Mogadishu on July 2. From May 30 to 31, 2015, Liu Guijin, Special Envoy for China-Africa Cooperation Forum of the Ministry of Foreign Affairs of China, visited Somalia. On June 24, 2015, the Economic and Commercial Counsellor's Office of the Chinese Embassy in Somalia officially opened its office.

\subsection{Cooperation Process}

At the end of 1990, the civil war in Somalia broke out. Because of this chaotic situation, many countries' embassies in Somalia have been withdrawn, even China is no exception. However, unlike the United States, although China has withdrawn its ambassador, for 20 years, it has not given up its aid to this land. China has been helping Somalia to build infrastructure free of charge. This is simply good news for the Somali people who live in the flames. Also because of China's selfless help, their perception of the Chinese has gradually changed, and the unhappiness caused by the withdrawal of the embassy has been bridged. The country sincerely thanks China for its help.

Although the war in Somalia is fierce, its demand for manufactured products and daily necessities is still strong, and because of its poor consumption capacity, its expectations for Chinese products are even higher. Habib, the concierge officer of the Ministry of Foreign Affairs of Somalia, once said, "Everything is made in China, the world cannot be separated from China, and Somalia needs China!” Even Somali businessman Ali Gia, who has shipping branches in many cities around the world, Bo said: "China's strong infrastructure construction capacity and manufacturing industry can well help the development of Somalia, which is awaiting development. Somalia needs China."

Until June 30, 2014, in order to further promote the development of friendly and cooperative relations between China and Somalia, China decided to resume 
the embassy in Somalia, and sent a restoration team to Somalia on July 1. Perhaps it is precisely because of China's help that chaos in Somalia is not hostile to China.

Despite the extremely difficult situation in Somalia, there is likely to be hope for the country to emerge from the crisis in the near future. Somalia and Djibouti mentioned that other countries along the coast of the Indian Ocean and the Mediterranean are very important to the Belt and Road Initiative and the 21st Century Maritime Silk Road project. The Belt and Road Initiative is extremely important to China. It cannot be ruled out that this has forced China to take effective measures to restore Somalia's economy and return the country to the path of peaceful development. In recent years, China has resumed its investment in Somalia and focused on the development of bilateral trade. In the five years from 2015 to 2019, China's trade with Somalia has increased by more than 10\% each year. China has become Somalia's largest international trading partner. In 2006, the bilateral trade volume between China and Somalia was US\$750 million, an increase of $14.9 \%$ year-on-year, of which Chinese exports were US $\$ 731$ million, an increase of $14.95 \%$, and imports were US $\$ 19$ million, an increase of 13.06\% (Maweu, 2016). Specific trade data are shown in Figure 3.

Although compared with other countries, the total trade volume between the two sides is not large, but considering the years of war in Somalia, the cooperation between China and Somalia has now re-entered a good stage of sustainable development, and the trade structure has evolved from traditional single aid to Bilateral economic and trade cooperation, capacity cooperation, and industry docking; at the same time, Chinese companies have also begun to increase investment in engineering construction in Somalia. In 2019, our company signed a new project contract value of 29.71 million US dollars in Somalia. The strengthening of infrastructure will inevitably bring more cooperation in the economic and trade field, China will continue to maintain Somalia's position as the largest trading partner and largest source of imports.

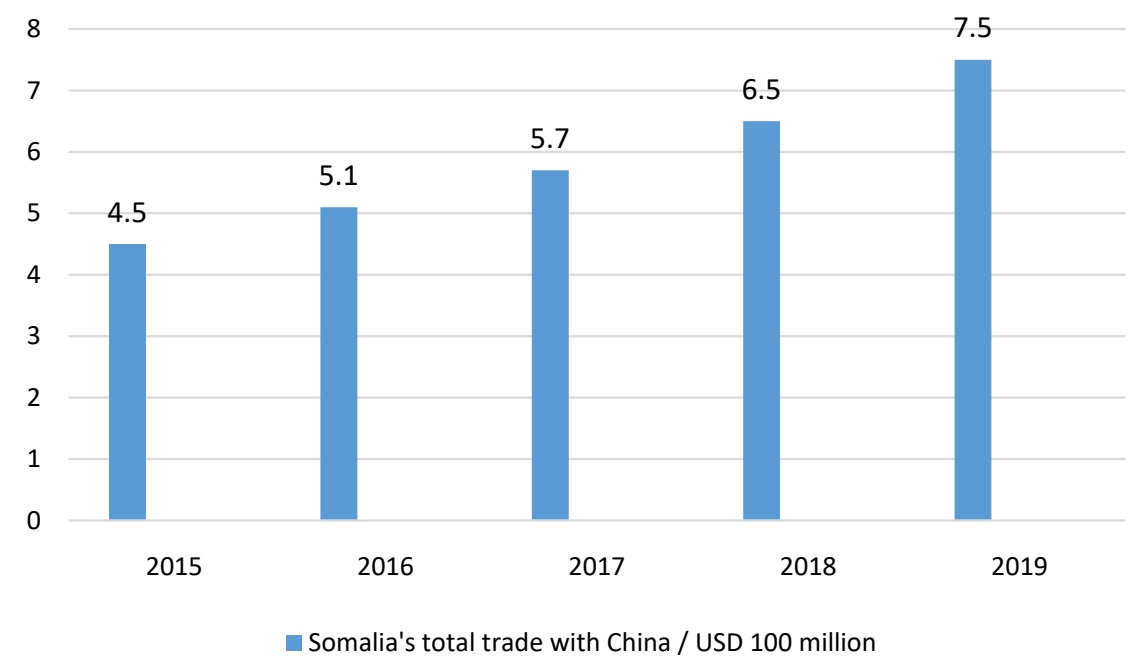

Figure 3. Somalia' total trade with China. 


\section{Problems in China-East Africa Economic and Trade Cooperation}

\subsection{The Domestic Political Situation and Security Situation in East African Member States Are Not Very Stable}

The unstable domestic political situation and security situation of East African member states is one of the main reasons hindering economic and trade cooperation between China and East Africa. The member states of East Africa have great instability in the political structure and security situation, among which Burundi and South Sudan are the main ones. After the civil war broke out in South Sudan in 2013, the political and security situation in the country was very unstable. After the political crisis broke out in Burundi in 2015, domestic violence occurred frequently and its nationals fled to neighboring countries to take refuge. Affected by the civil war and violence, there are huge risks in economic and trade cooperation between China and East Africa. In addition, Kenya's religious conflict is particularly evident (Mingdong, H. \& Farm, 2014). Muslims in the country pray regularly every day, and Chinese companies cannot avoid hiring Muslim employees when recruiting employees locally, and the prayer times of these personnel conflict with the progress of company projects in some ways, which is not conducive to economic and trade cooperation between the two countries.

\subsection{Lack of Certain Ability to Resist Trade Risks}

Since the economic and trade cooperation between China and East Africa, there is a lack of ability to resist trade risks. According to relevant statistics, in the course of economic and trade cooperation between China and East Africa, the economic and trade volume in 2001 and 2009 declined. Especially in 2009, the trade volume between China and East Africa dropped by as much as 60\% (Maxi, 2008). The main reason for this phenomenon is that the economic and trade cooperation mechanism between China and East Africa is not perfect, and the East African member states have a high degree of economic dependence on $\mathrm{Eu}$ ropean and American countries, which leads to the lack of a certain ability to resist trade risks.

\subsection{Imbalance in Trade between China and East Africa}

Since the establishment of the China-Africa Forum in 2000, China's relations with African countries have developed well, and the absolute value of China's net exports to East African countries has gradually decreased, and the trade balance between the two sides has gradually stabilized and is moving in a good direction. However, due to the impact of global economic integration and the financial crisis in recent years, the economic and trade cooperation between China and some countries in East Africa has experienced large fluctuations, which has caused the originally stable trade to start to become unbalanced. The main reason for this phenomenon is the impact of the structure of China's and East 
African import and export products. Most of the products exported from East Africa to China are mainly agricultural products and mineral resources, while those imported from China are mainly textiles and clothing (Weizhong, 2011). As a result, the price difference between import and export products between East African countries and China is large, and the demand for products between China and East Africa is not balanced, resulting in a great imbalance in trade between China and East Africa.

\section{China and East Africa Economic and Trade Cooperation}

\subsection{Strengthen Political Cooperation and Create a Stable Environment for Economic and Trade Development}

At present, the domestic political structure of East African member countries is volatile, which hinders the economic and trade cooperation between the two sides to a certain extent. To this end, East African member states first need to stabilize the domestic political situation and provide a stable development environment for bilateral economic and trade cooperation. Secondly, East African member states should also deepen policy information exchange with China in order to provide a stable development environment for bilateral trade cooperation. With China's "Belt and Road" initiative, trade cooperation can be developed with the help of the "Belt and Road" initiative. China can help East African member countries develop their domestic infrastructure construction, so that the economic and trade cooperation between the two sides can be further developed.

\subsection{Strengthening the Ability to Resist Trade Risks}

In order to strengthen the economic ties between China and East Africa, both China and East African member states should encourage domestic enterprises to engage in deeper economic cooperation in order to effectively improve the ability of both sides' economic and trade cooperation to resist trade risks. With the gradual deepening of trade cooperation between China and East African member countries, the investment and financial needs between China and East Africa will also become stronger. China should encourage domestic enterprises to invest in East African member countries, conduct financial activities, or directly establish multinational enterprise alliances in order to promote bilateral economic and trade cooperation and further enhance their ability to resist trade risks.

\subsection{Adopting Various Measures and Methods to Alleviate the Imbalance in Bilateral Trade}

With the increasingly fierce international trade environment, the trade environment between China and East Africa is complex and diverse. In addition, the laws and regulations on economic and trade cooperation between China and East Africa are not complete. East Africa is greatly affected by the European and 
American economies, resulting in great imbalances in trade between China and East Africa. In this regard, both China and East Africa should actively adjust their foreign trade policies and give them policy support in economic and trade cooperation. In addition, China and East Africa should, as far as possible, be in line with international standards when formulating relevant laws and regulations, so as to protect the legitimate rights and interests of both sides and promote the common economic development of China and East African member states.

\section{Acknowledgements}

Thanks to my teachers and classmates. You gave me a lot of inspiration and suggestions for my thesis, and gave me a lot of confidence. Wish all teachers and classmates a smooth job.

\section{Conflicts of Interest}

The author declares no conflicts of interest regarding the publication of this paper.

\section{References}

Fredrik, S. (2008). The Interplay between EU Member States and the EU: The Case of Development Cooperation in East and Southern Africa. IEEE International Conference on New Trends in Information Science \& Service Science.

He, W. P., \& Li, Y. X. (2014). New Developments in Economic and Trade Cooperation and Cultural Exchanges between China and Africa. International Understanding, No. $1,5-8$.

Jianxin, C. (2016). The Contribution of China-Africa Development Fund to the Industrial Capacity Cooperation between China and Africa. West Asia and Africa, 28, 15-20.

Maweu, J. M. (2016). Journalists and Public Perceptions of the Politics of China's Soft Power in Somalia under the "Look East" Foreign Policy. https://doi.org/10.1057/9781137539670 9

Maxi, S. (2008). China and Africa: Whose Challenge and Whose Opportunity? Africa Spectrum, 43, 403-413.

Mingdong, H., \& Farm, L. F. (2014). Overview on Kenya's Forestry. World Forestry Research, 13, 24-28.

Skjerdal, T. S. (2009). Between Journalism Universals and the Development of a Journalism Programme in an East African Context. Journal of African Media Studies, 1, 23-34. https://doi.org/10.1386/jams.1.1.23 1

Stahl, A. K. (2012). Trilateral Development Cooperation between the European Union, China and Africa: What Prospects for South Africa?

Weizhong, X. (2011). Challenges and Opportunities in Development Cooperation between China and Traditional, Donors in Africa. Modern International Relations: English Version, 21, 46-56.

Zhang, Q. J., \& Hu, Z. Z. (2016). The Path Strengthening Scientific and Technological Cooperation between China and Somalia. Global Sci-Tech Economic Outlook, 31, 57-65. 